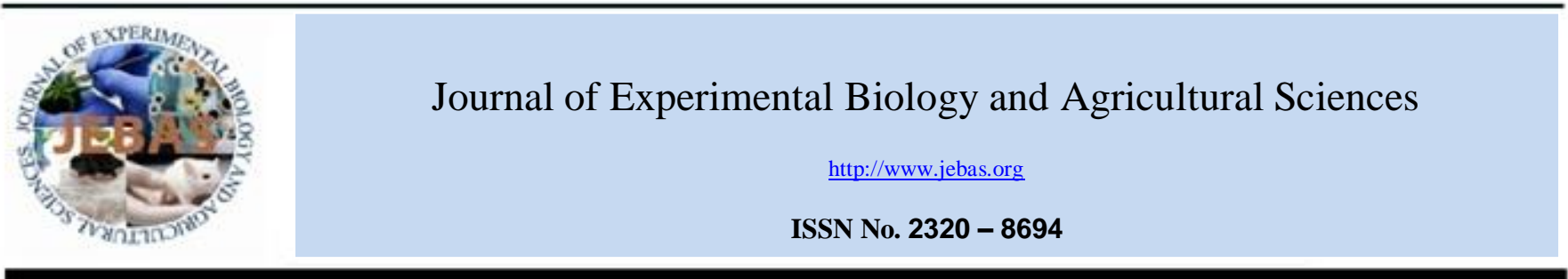

\title{
MOLECULAR IDENTIFICATION AND GROWTH INHIBITION OF SOME HUMAN PATHOGENIC BACTERIA ISOLATED FROM KING FAHAD GENERAL HOSPITAL, JEDDAH
}

\author{
Maaly Hassan Ali ${ }^{1}$, Fotoon Sayegh ${ }^{1,2}$, Samyah D. Jastaniah ${ }^{1}$ and Magda M. Aly ${ }^{1 *}$ \\ ${ }^{\mathbf{1}}$ Biology Department, Faculty of Science, King Abdulaziz University, P.O. Box 80203, Jeddah 21589, Saudi Arabia \\ ${ }^{2}$ Marine Natural Products Research Unit, King Fahd Medical Research Center, King Abdulaziz University, Jeddah 21589, Saudi Arabia
}

Received - September 29, 2017; Revision - October 20, 2017; Accepted - October 29, 2017

Available Online - October 31, 2017

http://dx.doi.org/10.18006/2017.5(5).690.696

KEYWORDS
Antibacterial activity
Actinomycetes
Streptomyces
Human pathogenic bacteria
Saudi Arabia

* Corresponding author

E-mail: magdammali@hotmail.com; mmmohammad@kau.edu.sa (Magda M. Aly)

Peer review under responsibility of Journal of Experimental Biology and Agricultural Sciences.

Production and Hosting by Horizon Publisher India [HPI] (http://www.horizonpublisherindia.in/).

All rights reserved.

\begin{abstract}
Antimicrobial properties of bacterial antagonist against human pathogenic bacteria have become a field of increasing importance in the medical sector. The present study has been carried out to identify the antimicrobial properties of actinomycetes bacteria against five human pathogenic bacteria viz., Staphylococcus aureus, Streptococcus pyogenes, Pseudomonas aeruginosa, Acinetobacter baumannii and Escherichia coli isolated from many wound swabs, from different service units of King Fahad General Hospital (KFGH), Jeddah. These isolated bacterial isolates were identified by using morphological and physiological characters along with molecular techniques. The antibacterial activities of five actinomycetes species along with Ampicillin $(5 \mu \mathrm{g} / \mathrm{ml})$ as positive control were also determined against the multidrug resistant $S$. aureus, $S$. pyogenes, $P$. aeruginosa, A. baumannii and $E$. coli by using disc diffusion assay. Result of study revealed that among the tested five actinomycetes species, Streptomyces 5 (St 5) was highly effective against P. aeruginosa, S. aureus, S. pyogenes and E. coli while it showed weak activity against A. baumannii. As compared to this, Streptomyces 2, 3 and 4 showed moderate antibacterial activities while Streptomyces 1 showed the lowest activity. Further, all the tested Streptomyces extracts and Ampicillin were found weak against the multi-drug resistant $A$. baumannii. In conclusion, actinomycetes especially genus Streptomyces can be used as a safe and effective source against multidrug resistant bacteria.
\end{abstract}

All the article published by Journal of Experimental Biology and Agricultural Sciences is licensed under a Creative Commons Attribution-NonCommercial 4.0 International License Based on a work at www.jebas.org.

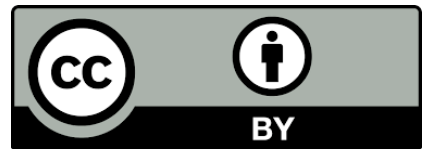




\section{Introduction}

Excess use of antibiotic, not only developed multidrug resistance in human pathogenic microorganisms. Indiscriminate uses of these drugs were leading to the selection of the bacterial pathogens, resistant to multiple antibiotics (Grasso et al., 2016). Resistance in bacteria against multiple drugs was due to the accumulation of multiple resistance genes against different drugs on the plasmids and/or the increase in gene expression that code for multidrug efflux pumps (Service, 1995, Nikaido, 2009). In addition to this, sometimes excess use of antibiotics are associated with various adverse effects such as hypersensitivity, immunesuppression and allergic reactions (Ahamed et al., 1998). Further, certain bacterial strains developed mechanisms or produced substances which block the action of antibiotics or change their target or ability to penetrate cells (Ali et al., 1995). Therefore, disease causing microbes that have become resistant to antibiotics are increasing public health problems and this forced scientists to search alternative to antibiotics which have good bactericidal activities.

Actinomycete metabolites have great bactericidal effects and therapeutic values against wide range of microorganisms. Further, antimicrobial activities of these actinomycetes are depending on the method of extraction. These metabolites can be used as alternative drugs with antibacterial or antifungal or antioxidant activities which protect the host from cellular oxidation (Singh et al., 2014). Zothan et al. (2017) reported that methanolic extract of $S$. cyaneofuscatus inhibited the growth of E. coli, P. aeruginosa, Micrococcus luteus S. aureus, and Candida albicans with $\mathrm{IC}_{50}$ ranged from 2.1-43.63 $\mu \mathrm{g} / \mathrm{ml}$. This antimicrobial activity may be due to the interaction of these metabolites with bacterial cell surface and causing structural changes, damaging, disturbing vital cell functions such as permeability, depressing the activity of respiratory chain enzymes, and finally leading to cell death (Demain, 1999, Ueda \& Beppu, 2017).

The aim of the present study was to evaluate the antimicrobial activities of some actinomycetes against multidrug resistant bacteria, isolated from local hospital.

\section{Materials and Methods}

All the required chemicals for this study were purchased from Merck, Germany and Sigma- Aldrich, USA.

\subsection{Collection and isolation of bacterial isolates:}

Sterile cotton swabs, moistened with sterile saline, were used to obtain samples from different patient wounds at King Fahad General Hospital, Jeddah, Saudi Arabia. Preliminary experiments were carried out to select antibiotics resistant bacteria, which have resistant against at least 3 most commonly used antibiotics. Wound samples were collected in two swabs, among these, one swab was used for Gram staining and the other one was inoculated on Mac-conkey and blood agar plates for isolating the different bacterial pathogens. Isolated Acinetobacter baumannii was identified by culturing this bacterium on Leeds Acinetobacter medium (Hardy Diagnostics, USA, catalog no. G261). The inoculated plates were incubated at $37^{\circ} \mathrm{C}$ overnigh and examined for growth. Isolated colonies were identified on the basis of morphological characteristic and biochemical tests including Catalase, Oxidase, Urease, Indole, Methyl Red, Voges Proskauer and Citrate Utilization tests as described by Koneman et al., (2005). The pure cultures of the tested bacteria were maintained on Nutrient agar slants at $4^{\circ} \mathrm{C}$ and in Glycerol Broth $\left(16 \mathrm{ml}\right.$ glycerol $+84 \mathrm{ml}$ nutrient broth) at $-70^{\circ} \mathrm{C}$.

\section{Molecular identification of the bacterial isolates}

For PCR, required DNA templates were obtained from overnight bacterial cultures that were collected, re-suspended in $200 \mathrm{ml}$ of sterile distilled water, and boiled for 1 minute (Usein et al., 2009). Species specific gene uid A for E. coli, ecfX for Pseudomonas areuginosa, oxa-51 for A. baumannii and 16S rRNA for Staphylococcus aureus and Streptococcus pyogens were used for the identification the detection particular bacterium (Clifford et al., 2012). Primers for uidA (E. coli) were prepared as according to the method described by Moyo et al. (2007), while oxa-51 (A. baumannii) primers were according to Brown \& Amyes (2005), and ecfX primers ( $P$. aeruginosa) were according to Clifford et al. (2012). The universal 16S rRNA primers were prepared as according to Tork et al., (2016). PCR performed in the Takara thermal cycler (Takara, Tokyo, Japan) and the PCR products were separated by using $1.5 \%$ agarose in Tris-acetate-EDTA buffer at $100 \mathrm{~V}$ and visualized. O'Range Ruler ${ }^{\mathrm{TM}} 100+500$ bp DNA Ladder, ready-to-use was included in each run.

\subsection{Isolation of actinomycetes}

The five Actinomycete isolates were obtained from Department of Botany, Faculty of Science, Tanta University, Egypt. These collected isolates were identified as Streptomyces exfloliatus ( $\mathrm{St}$ 1) and $S$. niveus (St 2) as per guide line given by Agwa et al. (2000), while S. anulatus SM 21 (St 3) and S. coelicolor SM 1 (St 4) were identified as guideline given by Aly et al., (2011). Further, S. exfoliates LP10 (St 5) was identified as method given by Aly et al. (2012).

\subsection{Estimation of Antimicrobial activity by agar well diffusion method}

Standard agar well diffusion method was carried out to detect the activity of Actinomycete filtrates against some selected 
pathogenic bacterial isolates (Cheesbrough, 2000). Each actinomycete isolate was cultured in $50 \mathrm{ml}$ of starch nitrate broth for 2 days at $25^{\circ} \mathrm{C}$ and healthy cells were collected and used to inoculate in $50 \mathrm{ml}$ of production broth medium, composed of $(\mathrm{g} / \mathrm{l})$ $10 \mathrm{~g}$ glucose, $1.0 \mathrm{~g} \mathrm{~K}_{2} \mathrm{HPO}_{4}, 1.0 \mathrm{~g} \mathrm{MgSO}_{4}, 7 \mathrm{H}_{2} 0,1.0 \mathrm{~g} \mathrm{NaCl}, 1.2 \mathrm{~g}$ $\mathrm{NH}_{4} \mathrm{NO}_{3}$, and $2.0 \mathrm{~g} \mathrm{CaCO}_{3}$ (Agwa et al., 2000). After 7 days, cell free culture filtrate was collected for each organism and extracted with the same volume of methanol (V/V). The methanol extract was dried, dissolved in DMSO and the antibacterial activities were determined on nutrient agar on which $100 \mu \mathrm{l}$ of the overnight suspension of each bacterial pathogen was spread. Using sterile cork borer $(8 \mathrm{~mm})$, agar well was made and filled with $50 \mu 1$ of the prepared actinomycete extract in DMSO or $5 \mu 1$ ( 5 $\mathrm{mg} / \mathrm{ml}$ ) of the standard antibiotic (positive control) under aseptic conditions. Then, the plates were kept in refrigerator for 2 hours before incubation to permit diffusion of the extract and incubated at $37^{\circ} \mathrm{C}$ for $24 \mathrm{hr}$, this was followed by the examination of antibacterial activity (diameter of inhibition zone, $\mathrm{mm}$ ). Duplicate plates were used for each tested bacterial pathogen.

\section{Results and Discussion}

In wound infections, many aerobic and anaerobic bacteria are found which lead to morbidity or prolonged hospitalization (Bowler et al., 2001). From last few decades, the emergence of antibiotic resistance in pathogenic isolates of human pathogenic bacteria is a dangerous threat to worldwide public health. This became more serious in case of Gram-negative bacteria such as $A$. baumannii, E. coli and P. aeruginosa and Gram-positive $S$. aureus which were associated with pus and wound infections, due to extensive prescription and inadequate dose of antibiotics (Rice, 2006, Misic et al., 2014). Rapid spread of multidrug resistant bacteria poses a serious threat to public health due to the limited treatment options and the decrease in the discovery of new classes of antibiotics (Iredell et al., 2016).

Bacterial identification is very important to reduce morbidity and mortality in patients. Good identification of the bacterial pathogens improves treatments options and lead to successful therapy (Barenfanger et al., 1999). In this study, five human pathogenic bacteria viz., Staphylococcus aureus, Streptococcus pyogenes, $P$. aeruginosa, A. baumannii and E. coli were isolated from wound of regular visiting patients of KFGH and identified by using conventional as well as molecular identification techniques. Among the isolated microorganisms, 16S rRNA primer was used for the identification of $S$. pyogenes and $S$. aureus while ecfX, uidA and bla oxa-51 were used for identification of $P$. aeruginosa, E. coli and A. baumannii respectively (Figures 1 and 2). The results of bacterial identification by using $16 \mathrm{~S}$ rDNA are in agreement with the findings of Weisburg et al. (1991). Similar findings was reported by Zhang et al. (2014) those who reported that predominance of $E$. coli, $S$. aureus, and $P$. aeruginosa in pus samples from patients with severe intra-abdominal infection. In another study, $S$. aureus was identified as the dominant bacterial species from wounds and this was followed by $P$. aeruginosa, P. mirabilis, E. coli (Lorrot et al., 2014). Acinetobacter baumannii is a nosocomial pathogen which affects critically ill patients and has increased importance. Further, Aly et al. (2014) recorded resistance nature of A. baumannii against various commonly used

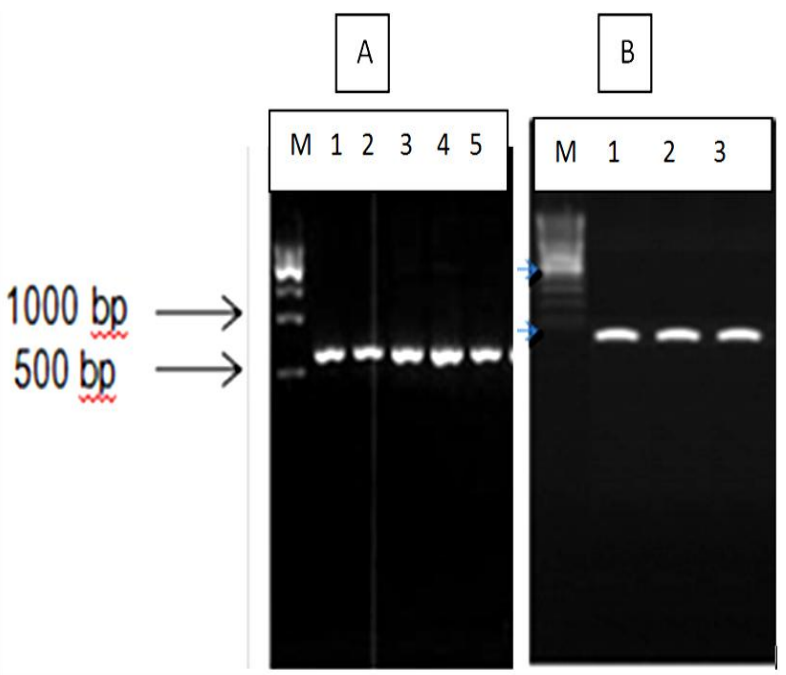

Figure 1 A: Agarose gel electrophoresis of PCR product of amplified uidA gene (623 bp). Lane M: Marker, Lane 1 positive control, Lane 2-5: positive strains for uidA gene. B: Agarose gel electrophoresis of PCR product of amplified ecfX gene. Lane M: Marker, Lane 1: positive control for ecfX gene,Lane 2-3 positive strains for ecfX gene.

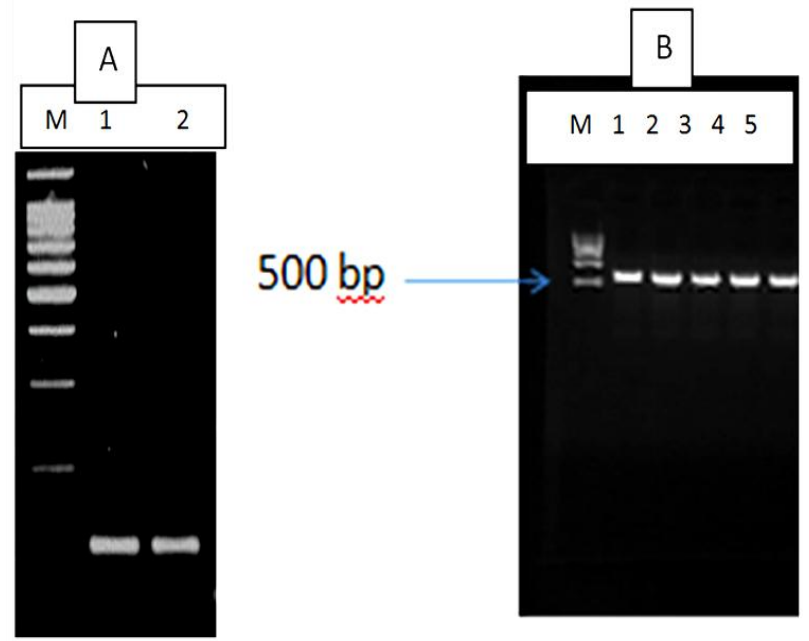

Figure 2 A: Agarose gel electrophoresis of amplified PCR product of oxa- 51 gene B: PCR product 16S rRNA gene. Lane M: Marker, Lane 1 positive control, Lane 2-5: positive strains for 16S rRNA gene. 

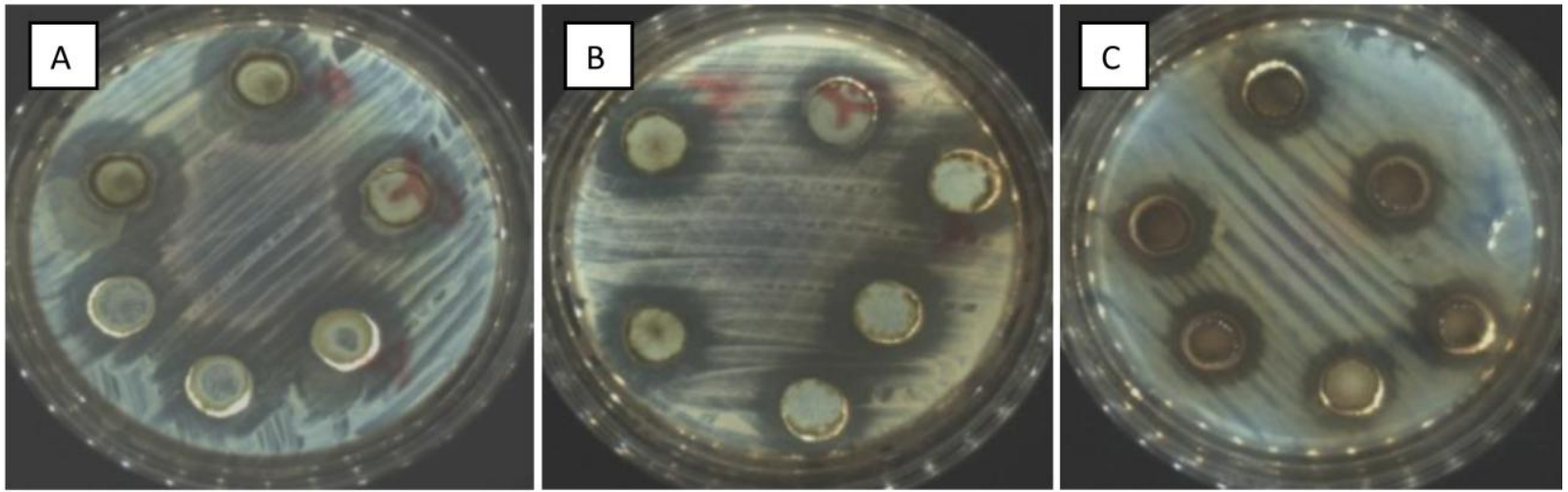

Figure 3 The effect of mthanol extracts of the five tested Streptomyces species on S. aureus (A), E. coli (B) and $S$ pyogenes (C).
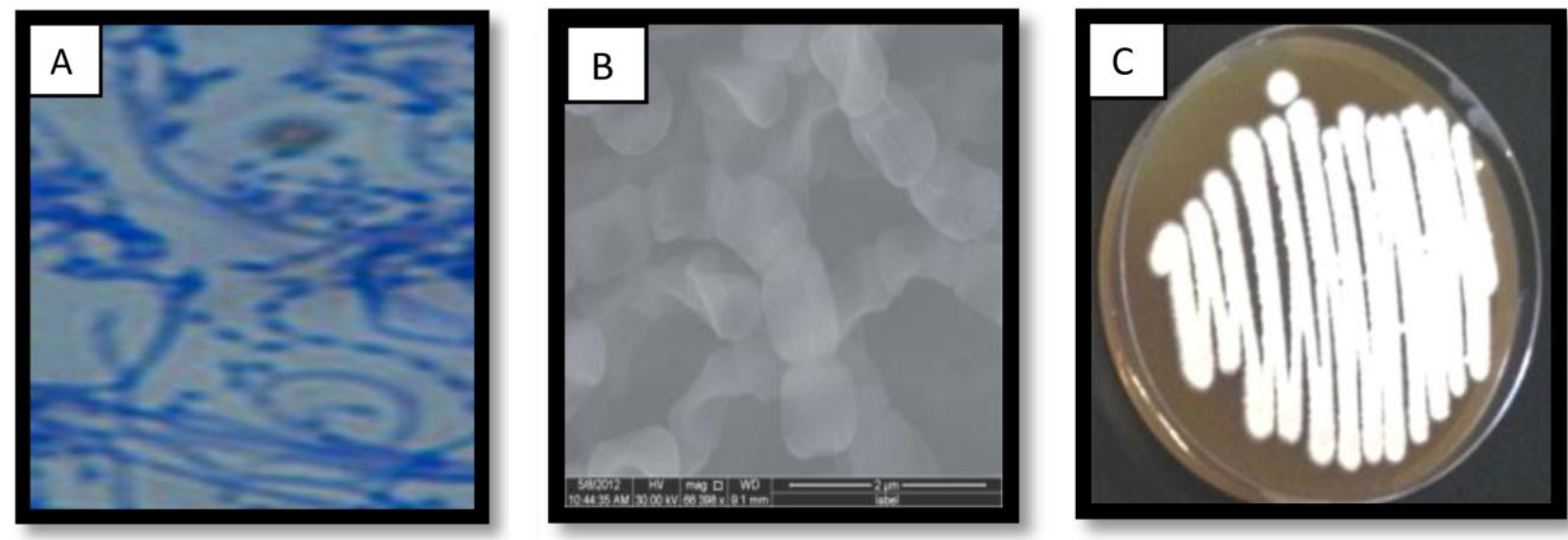

Figure 4 The selected Streptomyces isolate (St 5) under light microscope (A), scanning electron microscope (B) and on starch nitrate agar (C).

antibiotics. There is an evidence that carbapenemase gene was naturally occurred in A. baumannii (Al Masoudi et al., 2013).

Actinomycetes have highly significant roles in drug discovery and have provided bioactive secondary metabolites with interesting activities such as antimicrobial, antiviral and anticancer. An antimicrobial activity of actinomycete extracts varies with the tested bacterial isolates and the used pathogens (Bruntner et al., 2005, Bhave et al., 2013). In this study, methanolic extracts of the five Streptomyces species were found affective against the tested resistant bacteria (Figure 3) and S. exfoliates (St 5) was the most affective one with highest inhibition zone against $P$. areuginosa (27 mm), E. coli $(25 \mathrm{~mm})$, A. baumannii (18mm), S. pyogens $(25$ $\mathrm{mm})$ and finally $S$. aureus $(24 \mathrm{~mm})$ as shown in Table 1 . The growth and morphology of the $S$. exfoliates were shown in Figure 4. From past seven decades, the antibiotics obtained from actinomycetes have many successes. Actinomycetes are a sustained mine of new antibiotics with many mode of action that kills the pathogens without harming the host. Further, erythromycin, tetracyclines, aminoglycosides, daptomycin, tigecycline are the most common antibiotics which obtained from various actinomycetes. Among the identified bioactive compounds that have been obtained so far from microbes, $45 \%$ are produced by actinomycetes while $38 \%$ by fungi and $17 \%$ by unicellular eubacteria (Mahajan \& Balachandran, 2012). Result of study revealed that all the tested methanolic extracts of Streptomyces have good antibacterial activity against all tested bacteria except for A. baumannii and among the tested microbes, maximum antibiotic activity was reported against $P$. areuginosa and $S$. pyogenes while in case of conventional antibiotic, maximum activity of Ampicillin was reported against $S$. pyogenes with inhibition zone of $19 \mathrm{~mm}$. The antimicrobial ability of Streptomyces might be referred to their effect on the cell wall of the bacteria which finally causing the destruction of cell wall and death of bacteria. Also, the extracts interact with the building elements of the outer membrane and might cause structural 
Table 1 The antibacterial activity (diameter of inhibition zone $\mathrm{mm}$ ) of the methanolic extracts of five actinomycete isolates against some bacterial pathogens

\begin{tabular}{|c|c|c|c|c|c|}
\hline \multirow{2}{*}{$\begin{array}{l}\text { Tested } \\
\text { actinomycetes }\end{array}$} & \multicolumn{5}{|c|}{ Zone of inhibition $(\mathrm{mm}) \pm \mathrm{SEM}$ in various bacterial isolates } \\
\hline & $\begin{array}{r}P . \\
\text { areuginosa }\end{array}$ & $\begin{array}{c}\text { A. } \\
\text { baumannii }\end{array}$ & $\begin{array}{c}E . \\
\text { coli }\end{array}$ & $\begin{array}{r}S . \\
\text { pyogenes }\end{array}$ & $\begin{array}{r}S . \\
\text { aureus }\end{array}$ \\
\hline Streptomyces 1 & $14 \pm 2.1$ & $9 \pm 1.0$ & $9 \pm 2.0 *$ & $18 \pm 0.8$ & $14 \pm 0.9$ \\
\hline Streptomyces 2 & $25 \pm 1.7 *$ & $9 \pm 1.1$ & $18.3 \pm 1.1$ & $25 \pm 1.9$ & $19 \pm 0.1$ \\
\hline Streptomyces 3 & $20 \pm 1.5^{*}$ & $9 \pm 2.3$ & $8 \pm 1.0^{*}$ & $19 \pm 1.1$ & $19 \pm 2.9$ \\
\hline Streptomyces 4 & $14 \pm 2.3$ & $11 \pm 1.0$ & $19 \pm 2.4$ & $24 \pm 2.5$ & $14 \pm 2.9$ \\
\hline Streptomyces 5 & $27 \pm 1.6^{*}$ & $18 \pm 1.1 *$ & $25 \pm 2.4^{*}$ & $25 \pm 2.6$ & $24 \pm 2.0$ \\
\hline $\begin{array}{l}\text { Ampicillin } \\
\text { (control) }\end{array}$ & $17 \pm 1.6$ & $11 \pm 1.0$ & $17 \pm 2.1$ & $19 \pm 1.5$ & $15 \pm 1.3$ \\
\hline
\end{tabular}

*: Significant results compared to control

changes; degradation and finally cell death. Also, antibacterial activities of the extracts could be due to the susceptibility of pathogens cell wall and toxicity in addition to the change in membrane potential, inhibition of ATP syntheses and levels leading to collapse of all biological process (Cui et al., 2012). Similar results were reported by Srinivasan et al. (2009) who reported strong antibacterial activity against Gram-positive than the gram-negative bacteria, this may be due to the structure differences in cell wall structure, where Gram negative has outer membrane which block the penetration of antibiotics and plant extracts and making them resistant against various antibiotic substances. Extract of Streptomyces 5 was more effective as compared to other methanolic extracts of actinomycetes and it is equally effective against all the tested microbes. Further, moderate antibacterial activities were recorded for the methanolic extracts of Streptomyces 2, Streptomyces 3 and Streptomyces 4 while Streptomyces 1 showed the least antibacterial activity. Antibiotics from actinomycetes may affect essential processes in bacterial cell wall biosynthesis and change bacterial structures and functions. Antibiotics essentially target cell membrane protein translation, RNA transcription, DNA replication and synthesis (Ueda \& Beppu, 2017). Glycopeptides are a class of drugs produced by Actinomycetes bind to the dipeptide D-alanyl--D-alanine of cell wall of Gram-positive bacteria preventing the addition of new units to the peptidoglycan and inhibiting the peptidoglycan synthesis (Demain, 1999, Ueda \& Beppu, 2017).

In conclusion, the antibiotics from actinomycetes must be intensively studied, their sources, structures, activities, and mode of actions and further research is required to use these safe and effective extracts in alternative medicines.

\section{Conflict of Interest}

Authors would hereby like to declare that there is no conflict of interests that could possibly arise.

\section{References}

Agwa H, El-Shanshoury AR, Aly M, Bonaly R (2000) Isolation and characterization of two Streptomyces species producing antifungal agents. Journal Union Arab Biology 9: 283-303.

Ahamed I, Mehmood Z, Mohammad F (1998) Screening of some Indian medicinal plants for their antimicrobial properties. Journal Ethnopharmacology $183-193$.

Al Masoudi SB, Aly MM, Al humidi NQ, Halwani M (2013) Incidence and prevalence of Acinetobacter baumannii in King Fahd General Hospital, Saudi Arabia. Life Science Journal 10:1702-1710

Ali BH, Bashir AK, Tanira MO (1995) Anti-inflammatory, antipyretic and analgesic effects of Lawsonia inermis in rats. Pharmacolology $356-363$.

Aly MM, Tork S, Al Garni S, Nawar L (2012) Production of lipase from genetically improved Streptomyces exfoliates LP10 isolated from oil contaminated soil. African Journal of Microbiology Research 6: 1125-1137

Aly MM, Tork S, Alakilli SY (2011) Molecular characterization of chitiniolytic Bacillus pumilus, isolated from marine habitats and enhancement of chitinase production by mutation. Advanced Scholar in Biotechnology 1:14-21. 
Aly MM, Al Masoudi SB, Halwani MA, Al humidi NQ (2014) Prevalence and antimicrobial resistance of Acinetobacter isolates from King Fahd General Hospital, Saudi Arabia. Life Science Journal 11:226-233

Barenfanger J, Drake C, Kacich G (1999) Clinical and financial benefits of rapid bacterial identification and antimicrobial susceptibility testing. Journal Clinical Microbiology, 37:14151418 .

Bhave SV, Shanbhag PV, Sonawane SK, Parab RR, Mahajan GB (2013) Isolation and characterization of halotolerant Streptomyces radiopugnans from Antarctica soil. Letters in Applied Microbiology 56:348-55.

Bowler PG, Duerden BI, Armstrong DG (2001) Wound microbiology and associated approaches to wound management. Clinical Microbiology Reviews 14:244-269.

Brown S, Amyes SGB (2005) The sequences of seven class D beta-lactamases isolated from carbapenem-resistant Acinetobacter baumannii from four continents. Clinical Microbiology and Infection 11:326-329.

Bruntner C, Binder T, Pathom-aree W, Goodfellow M, Bull AT, Potterat O, Puder C, Hörer S, Schmid A, Bolek Wr, Wagner K, Mihm G, Fiedler H (2005) Frigocyclinone, a novel angucyclinone antibiotic produced by a Streptomyces griseus strain from Antarctica. Journal Antibiotic 58: 346-349.

Cheesbrough M (2000) District Laboratory Practice in Tropical Countries (Part 2 ). Cambridge University Press.

Clifford RJ, Milillo M, Prestwood J, Quintero R, Zurawski DV, Kwak YI, Waterman PE, Lesho EP, Mc Gann P (2012) Detection of bacterial 16S rRNA and identification of four clinically important bacteria by real-time PCR. PLOS One 7: e48558.

Cui Y, Zhao Y, Tian Y, Zhang W, Lux X (2012) The molecular mechanism of action of bactericidal gold nanoparticles on Escherichia coli. Biomaterials 33: 2327-2333.

Demain AL (1999) Pharmaceutically active secondary metabolites of microorganisms. Applied Microbiology and Biotechnology 52: $455-463$.

Grasso LL, Martino DC and Alduina R (2016) Production of Antibacterial Compounds from Actinomycetes. In: Dhanasekaran D, Jiang Y (Eds.) Actinobacteria, Basics and Biotechnological Applications. Intech Open Access Publication. DOI: DOI: $10.5772 / 61525$.
Iredell J, Brown J, Tagg K (2016) Antibiotic resistance in Enterobacteriaceae: mechanisms and clinical implications. British Medical Journal 352-355.

Koneman WK, Allen SD, Janda WM, Schreckenberger PC, Propcop GW, Woodsand GL and Winn WC (2005). Philadelphia Color Atlas and Textbook of Diagnostic Microbiology, 6th ed. Lippincott-Raven Publisher, Pp. 624-662.

Lorrot M, Bourrat E, Doit C, Prot-Labarthe S and Dauger S (2014) Superficial skin infections and bacterial dermohypodermitis. Archives of pediatrics 14: 162-166.

Mahajan GB, Balachandran L (2012) Antibacterial agents from actinomycetes - a review. Frontiers in Bioscince 1, 4:240-245.

Misic AM, Gardner S E, Grice E A (2014) The Wound Microbiome: modern approaches to examining the role of microorganisms in impaired chronic wound healing. Advances in Wound Care 3 : 502-510.

Moyo SJ, Maselle SY, Matee MI, Langeland N, Mylvaganam H (2007) Identification of diarhegenic Escherichia coli isolated from infants and children in Dar es salaam, Tanzania. BMC Infectious Diseases 9: 7-92.

Nikaido H (2009) Multidrug resistance in bacteria. Annual Review of Biochemistry, 78:119-46.

Rice LB (2006) Antimicrobial resistance in gram-positive bacteria. The American Journal of Medicine, 19:S11-S19.

Service RF (1995) Antibiotics that resist multidruging resistance. Sciences 270: 724- 727.

Singh LS, Sharma H, Talukdar NC (2014) Production of potent antimicrobial agent by actinomycete, Streptomyces sannanensis strain SU118 isolated from phoomdi in Loktak Lake of Manipur, India. BMC Microbiology 14: 278. doi: 10.1186/s12866-0140278-3.

Srinivasans D, Nathan S, Suresh T, Perumalsamy PL (2009) Antimicrobial activity of certain Indian medicinal plants used in folkloric medicine. Journal Ethnopharmacology 74: 217-220.

Tork SE, Shahein YE, El-Hakim AE, Abdel-Aty AM, Aly MM (2016) Purification and partial characterization of serinemetallokeratinase from a newly isolated Bacillus pumilus NRC21. International Journal of Biological Macromolecules 86: 189-196.

Ueda K, Beppu T (2017) Antibiotics in microbial coculture. The Journal of Antibiotics 70, 361-365; doi:10.1038/ja.2016.127. 
Usein CR, Tatu-Chitoiu D, Ciontea S, Condei M, Damian M (2009) Escherichia coli pathotypes associated with diarrhea in Romanian children younger than 5 years of age. Japanese Journal of Infectious Diseases 62: 289-293.

Weisberg WG, Barns SM, Pelletier DA, Lane DJ (1991). 16S Ribosomal DNA amplification for phylogenetic study. Journal Bacteriology 173: 697-703.

Zhang S, Ren L, Li Y, Li Y, Wang J, Yu W, Li N, Li J (2014)
Bacteriology and drug susceptibility analysis of pus from patients with severe intra-abdominal infection induced by abdominal trauma. Experimental and Therapeutic Medicine 7 :1427-1431

Zothan P, Passari AK, Chandra P, Leo VV, Mishra VK, Kumar B, Singh BP (2017) Production of Potent Antimicrobial Compounds from Streptomyces cyaneofuscatus Associated with Fresh Water Sediment. Frontiers of Microbiology 8:68. doi: 10.3389/fmicb.2017.00068. 